\title{
Oral cavity lesions: A study of 21 cases
}

\author{
Pudasaini $\mathrm{S}^{1}$, Baral $\mathrm{R}^{2}$ \\ ${ }^{1}$ Department of Pathology, Nepal Medical College, Kathmandu, Nepal \\ ${ }^{2}$ Department of Pathology, KIST Medical College and Teaching Hospital, Lalitpur, Nepal
}

\section{Keywords: \\ Oral cavity; \\ Fibroma; \\ Mucocele}

\begin{abstract}
Background: Development of lesions in the oral cavity is strongly linked with smoking and alcohol consumption. Non neoplastic lesions are mainly inflammatory conditions. It has been seen that the benign lesions are more common than malignant.
\end{abstract}

Materials and methods: This was a retrospective study carried out in the Department of Histopathology of Helping Hands Community Hospital during a period of one and a half years from January 2009 to June 2010. The study included 21 cases of oral cavity lesions.

Results: The most common site was lip with 9 cases $(42.8 \%)$ followed by buccal cavity with 5 cases $(23.8 \%)$. Out of the 21 cases of oral cavity lesions, 20 cases $(95.2 \%)$ were benign and 1 case (4.8\%) was malignant. The malignant lesion was a case of squamous cell carcinoma of soft palate.

Conclusion: Any oral cavity lesion should have a tissue diagnosis for rational management of the case and to avoid mutilating surgery.

\section{INTRODUCTION}

Oral cavity lesions are usually asymptomatic. The association between ill fitting dentures, tobacco chewing and cigarette smoking with pathological lesions, both benign and malignant, has been proven. Most of these lesions are benign with the commonest being inflammatory, hemangioma, fibroma, lipoma, mucocele and nevus. Among the malignant lesions, squamous cell carcinoma is the common carcinoma of oral cavity. The most common sites are lip, buccal cavity, tongue and palate.

\section{MATERIALS AND METHODS}

This is a retrospective study done in Department of Histopathology of Helping Hands Community Hospital

\section{Correspondence:}

Dr. Sujata Pudasaini, $M D$

Department of Pathology

Medical College Teaching Hospital, Jorpati, Kathmandu, Nepal.

E-mail: sujatap2000@yahoo.com for a period of one and half years (January 2009 to June 2010). A total of 21 specimens were processed, sectioned and stained with Hematoxylin and eosin stain and reviewed by pathologists. Histopathology reports were acquired from the data base of the lab. Data was analyzed using SPSS 17 version for windows.

\section{RESULTS}

The age range was from 12 to 68 years with a mean age of 46 years. The youngest patient (12 year old male) presented with mucocele of lower lip and the oldest patient (68 years old male) with chronic inflammation of upper arch buccal tissue. Lesions were more commonly seen in male (12 cases; $57 \%$ ) than in females ( 9 cases; $43 \%$ ). The more common age group $(47.6 \%)$ was 20 - 40 years followed by the age group above 60 years $(19 \%)$. Among 21 cases, 1 case $(4.8 \%)$ was malignant and 20 cases $(95.2 \%)$ were benign. The most common site was the lip (42.8\%). Other sites with number of cases were tabulated in Table 1. Different types of benign 
Table 1: Number of cases according to the sites

\begin{tabular}{lcc}
\hline Sites & Number of cases & Total \% \\
\hline Lip & 9 & $42.8 \%$ \\
Buccal cavity/cheek & 5 & $23.8 \%$ \\
\hline Palate & 3 & $14.3 \%$ \\
Maxilla & 2 & $9.5 \%$ \\
Gingiva & 1 & $4.8 \%$ \\
\hline Floor of the mouth & 1 & $4.8 \%$ \\
\hline
\end{tabular}

Table 2: Different type of benign and malignant oral cavity lesions.

\begin{tabular}{lcc}
\hline Lesions (types) & No. of cases & Percentage \\
\hline Chronic inflammation & 4 & $19 \%$ \\
\hline Hemangioma & 3 & $14.2 \%$ \\
\hline Fibroma & 2 & $9.5 \%$ \\
\hline Mucocele & 2 & $9.5 \%$ \\
\hline Nevus & 2 & $9.4 \%$ \\
\hline Squamous cell carcinoma & 1 & $4.8 \%$ \\
\hline Odontogenic tumor (adenoamelo- & 1 & $4.8 \%$ \\
blastoma) & 1 & $4.8 \%$ \\
\hline Radicular cyst & 1 & $4.8 \%$ \\
\hline Papillary adenoma & 1 & $4.8 \%$ \\
\hline Lipoma & 1 & $4.8 \%$ \\
\hline Trichoepithelioma & 1 & $4.8 \%$ \\
\hline Fibroepithelial polyp & 1 & $4.8 \%$ \\
\hline Papilloma & &
\end{tabular}

and malignant lesions were identified in the study and were tabulated in Table 2. A case of adenoameloblastoma is shown in fig.1.

\section{DISCUSSION}

The incidence of benign lesions in our study was 20 cases $(95.2 \%)$ and only one case was malignant. Similar finding was seen in a study done by Mujica et al where the majority of the lesions were benign and comprised of either inflammatory or reactive lesions. ${ }^{1}$ However, in a study done by Ntomonchtsis et al, the incidence of benign lesion in the lip was $33 \%$ and malignancy was $67 \%{ }^{2}$

In our study, the age range was 12 to 68 years with mean age of 46 years. This correlates well with many studies done in different parts of the world. In a study done in Northern Jordanian population by Khateeb et al, the mean age of the patient ranged from 6 to 98 years. ${ }^{3}$ In another study done by Furlong et al, the youngest patient was 9 years and the oldest was 92 years old. ${ }^{4}$ Peak incidence of oral cavity lesions were seen in age group 20 to 40 years which was comparable with study done by Al-Khateeb et al where the majority of lesions were seen in $2^{\text {nd }}$ to $4^{\text {th }}$ decade. ${ }^{3}$

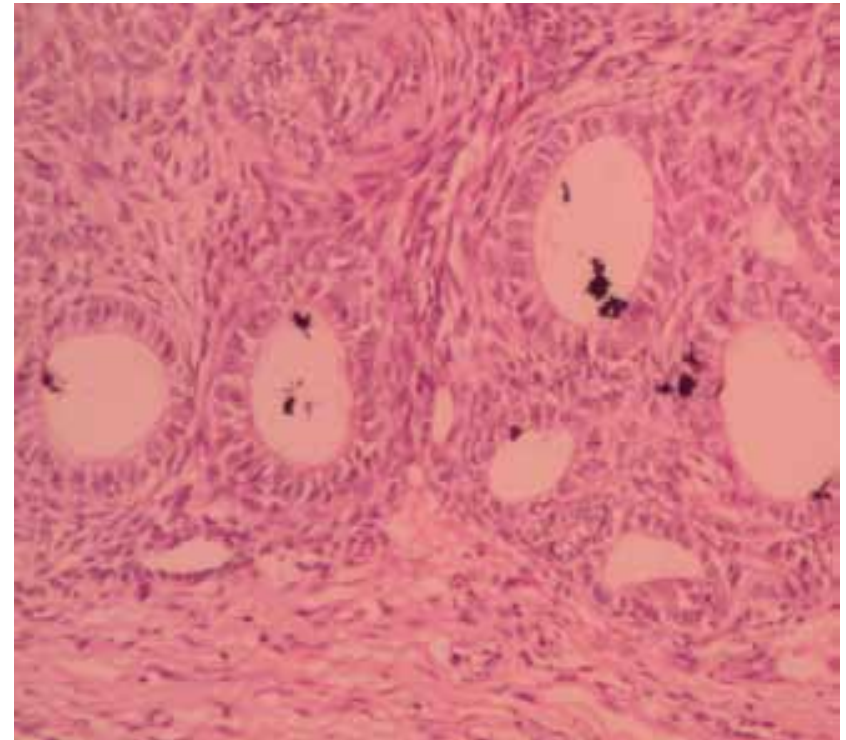

Figure 1: Adenoameloblastoma showing ductal structures lined by cuboidal epithelium and homogenous zones of hyaline material (HE, X20)

The most common site in our study was lip with 9 cases (42.8\%). In the study done by Al-Khateeb et al, the lip was the third common site and palate was the most common site. $^{3}$

There was 1 case of squamous cell carcinoma of soft palate in a 62 years old male. The patient was a known smoker who presented with white plaque like lesions of 8 months duration. In studies done by Ildstad et al and Weber et al, majority of the squamous cell carcinomas were seen in the 6th decade. ${ }^{5,6}$

Inflammatory lesions were seen in 4 cases (19\%). Among the non neoplastic lesions, $33 \%$ of inflammatory lesions were seen in a study done by Al- Khateb et al. ${ }^{3}$ There were 2 cases $(9.5 \%)$ of fibroma. Hemangioma was seen in 3 cases $(14.2 \%)$.

Mucocele was seen in 2 cases $(9.5 \%)$ and both cases occurred in the lower lip. Oliveira et al also showed that the lip was the common site for mucocele in his study where $52.3 \%$ cases were from the lip. ${ }^{7}$ Another study showed that mucoceles were more common in the lower lip. ${ }^{8}$

We found 2 cases (9.4\%) of nevi (one intradermal nevus and one compound nevus) in our study.

Trichoepithelioma is a benign hamartomatous tumor of the pilosebaceous follicle and is more commonly seen in the face. In our study, a 60 year old female was diagnosed with trichoepithelioma of the upper lip. She presented with rapidly growing nodule in the upper lip for a duration of one year. Bozi et al showed that lips were one of the common sites for trichoepithelioma. Other common sites were nasolabial fold, nose, forehead and eyelids. ${ }^{9}$ 
Adenoameloblastoma is a rare benign tumor of odontogenic origin. It occurs in young females with maxilla being the common site of presentation. There was 1 case of adenoameloblastoma of left maxilla in 13 year old female in our study.

Other benign lesions that we came across in our study were papillary adenoma, radicular cyst, lipoma, fibroepithelial polyp and papilloma. Studies have shown that these lesions are not very common but often occur in the oral cavity. ${ }^{2-4}$

\section{CONCLUSION}

In our study, we concluded that the most common oral cavity lesions were of benign nature. However, the origin and nature of the oral cavity lesions cannot be confirmed by clinical examination alone, hence, it is advisable to have a histopathological examination to confirm the nature of the lesion.

\section{REFERENCES}

1. Mujica V, Rivera H, Carrero M. Prevalence of oral soft tissue lesions in an elderly venezuelan population. Med Oral Pathol Oral Cir Bucal 2008;13:E270-4.
2. Ntomouchtsis A, Karakinaris G, Poulolpoulos A et al. Benign lip lesions. A 10-year retrospective study. Oral Maxillofac Surg 2010;14:115-8.

3. Al-Khateeb TH. Benign oral masses in a Northern Jordanian population- a retrospective study. Open Dent J 2009;3:147-53.

4. Furlong MA, Fanburg- Smith JC, Childers EL. Lipoma of the oral and maxillofacial region: site and subclassification of 125 cases. Oral Surg Oral Med Oral Pathol Oral Radiol Endod 2004;98:441-50.

5. Ildstad ST, Bigelow ME, and Remensnyder JP. Squamous cell carcinoma of the alveolar ridge and palate. A 15-year survey. Ann Surg 1984;199:445-53.

6. Weber RS, Peters LJ, Wolf P, Guillamondegui O. Squamous cell carcinoma of the soft palate, uvula, and anterior faucial pillar. Otolaryngol Head Neck Surg 1988;99:16-23.

7. Oliveira DT, Consolaro A, Freitas FJ. Histopathological Spectrum of 112 cases of mucocele. Braz Dent J 1993;4:29- 36.

8. Lopez JP. Labial mucocele; a study of eighteen cases. The Internet Journal of Dental science. 2006 [Cited 2011 Jan 10]. Available from: http://www.ispub.com/journal/the_internet_journal_of dental_science/volume_3_number_2_11/article_printable/labial_mucocele_a_study_of_eighteen_cases.html.

9. Bozi E, Katoulis AC. Multiple Familial Trichoepitheliomas (online). Orphanet Encyclopedia; April 2004 [cited 2011Jan 10]. Available from: http://www.orpha.net/data/patho/GB/uk-Trichoepithelioma. pdf. 